УДК 347.4

DOI https://doi.org/10.51989/NUL.2021.6.4

\title{
ОКРЕМІ ПРОБЛЕМНІ ПИТАННЯ НОРМАТИВНОГО КОРЕГУВАННЯ ПОРЯДКУ ОБЧИСЛЕННЯ ПОЗОВНОЇ ДАВНОСТІ
}

\section{Гуйван Петро Дмитрович,}

кандидат юридичних наук, заслужений юрист України, професор Полтавського інституту бізнесу

Стаття присвячена науковому дослідженню актуального питання про обґрунтованість та адекватність дійсних способів спеціального обчислення тривалості позовного домагання в контексті сутності такого правового явища, як позовна давність. У цьому контексті оцінено мораторій як передбачений ч. 2) ст. 263 ЦКУ спосіб відстрочення виконання зобов'язання. На базі ретельного дослідження можливого впливу мораторію на можливість подання позову, його розгляду чи виконання судового рішення автор дійшов висновку, що в нормативно встановленому вигляді він ніяк не може у цій іпостасі виступати як правова підстава для зупинення давності. За своєю правової ідеєю мораторій має встановлювати заборону на виконання (зокрема, примусове) такого зобов'язання і впливати не на стан самого цивільного правовідношення, а на можливість його реалізації. Отже, за своєю сутністю він $є$ не відстроченням виконання обов'язку, а забороною вчиняти певні види діяльності. А якщо так, то зупинення позовної давності у разі зупинення дії закону або іншого нормативно-правового акта, який регулює відповідні відносини, вже врегульовано пунктом 3 ч. 1 ст. 263 ЦКУ, тому відбувається невиправдане дублювання законодавчих правил. Також у роботі висвітлено стан проблеми з перериванням строку давності внаслідок визнання боргу боржником. Особлива увага приділена такому способу фіксації наявного боргу, як укладення договору на нових умовах щодо строків виконання за заявою до кредитора про відстрочення обов'язку. Установлено, що тут ідеться про відтермінування вже простроченого зобов'язання, з якого почалася позовна давність, але яким не завершилася. Цей правочин прийнято кваліфікувати як різновид дії боржника, що свідчить про визнання ним боргу, від моменту її укладення пропонується обчислювати новий давнісний перебіг. Однак виявлено, що така конструкція суперечить фактичній природі коментованих відносин, адже за такої угоди відбувається реструктуризація охоронного (порушеного) обов'язку, але виконання (зокрема, примусове) ще не може відбутися.

Ключові слова: зупинення позовної давності, мораторій, визнання боргу.

\section{Guyvan Petro. Certain problematic issues of regulatory adjustment of the procedure for calculating the limitation period}

This paper is devoted to the research of the topical issue of the validity and adequacy of existing methods of special calculation of the duration of claims in the context of the essence of such a legal phenomenon as statute of limitations. In this context, the moratorium is assessed as provided for in Part 2) of Art. 263 CCU method of deferral of performance. Based on a careful study of the possible impact of the moratorium on the possibility of filing a lawsuit, its consideration or execution of a court decision, the author concluded that in the normative form it can not in this form act as a legal basis for suspension. According to its legal idea, the moratorium should establish a ban on the performance (including coercion) of such an obligation and affect not the state of the civil relationship itself, but the possibility of its implementation. That is, it is not a postponement of a duty, but a prohibition to perform certain activities. And if so, the suspension of the statute of limitations in the event of suspension of the law or other normative legal act governing the relevant relations, is already regulated by paragraph 3 of Part 1 of Art. 263 of the CCU, so there is unjustified duplication of legislative rules. The paper also highlights the state of the problem with the interruption of the statute of limitations due to the recognition of the debt by the debtor. Particular attention is paid to such a way of fixing the existing debt, as the conclusion of an agreement on new terms on the terms of performance on the application to the creditor for deferral of debt. It has been established that this is a postponement of an already overdue obligation, according to the requirements of which the statute of limitations began but did not end. This transaction is usually classified as a kind of action of the debtor, which indicates 
the recognition of the debt, and from the moment of its conclusion, it is proposed to calculate the new long-standing course. However, it was found that such a construction contradicts the actual nature of the commented relations. After all, such an agreement is a restructuring of the security (violated) duty, but the implementation (including - compulsory) can not yet take place.

Key words: suspension of statute of limitations, moratorium, debt recognition.

Установлення початкового моменту існування позовного домагання ще не означає, що ми достеменно дізналися про термін його закінчення. Річ у тім, що чинне законодавство запроваджує певні юридичні механізми коригування порядку обчислення безперервного перебігу цього строку. Ідеться про зупинення та переривання позовної давності у випадках, передбачених ст. 263, 264 ЦКУ. При цьому слід ураховувати, що терміни «зупинення», «переривання» нормативно пов'язані з позовною давністю, однак не означають переривання чи зупинення часу як форми існування матерії. Ідеться лише про можливість зарахування певних відрізків часу до давнісних строків. Перелік підстав для вказаного в цих нормах коригування порядку обчислення позовної давності $\epsilon$ вичерпним. Скажімо, не можуть уважатися такими, що зупиняють давнісний строк, інші обставини, які унеможливлюють чи утруднюють звернення до суду, але не вказані в переліку ст. 263 ЦКУ, навіть коли вони $є$ досить суттєвими (тяжка хвороба, відсутність відомостей про порушення тощо). За певних обставин вони можуть впливати на відстрочення початку перебігу давності чи відновлення можливості захисту права, а не на зупинення давнісного строку.

Цілком логічно, що і переривання, і зупинення давнісного строку, відбудеться лише тоді, коли явища, які зумовлюють зазначені правові наслідки, мали місце протягом перебігу позовної давності. Скажімо, визнання боргу після задавнення відповідної вимоги не призведе до переривання строку, що вже закінчився $[1$, с. 4]. Не викликає сумнівів також той факт, що зупинення позовної давності не буде, коли чинники, які його зумовлюють, виникли чи відпали до початку перебігу строку. Сутність явищ, що $\epsilon$ підставами для зупинення перебігу давнісного строку, досить детально досліджена як у цивілістиці загалом, так і нами зокрема [2, с. $105 ; 3$, c. 254-275].
Одним із чинників, котрі впливають на зупинення давнісного перебігу (згідно із законом), $€$ непереборна сила. Ïї наявність унеможливлює подання позову або вчинення правосуддя. На відміну від непереборної сили явища, передбачені частинами 2), 3) статті 263 ЦКУ, не перешкоджають зверненню до юрисдикційного органу, а унеможливлюють винесення судом рішення про захист порушеного права. Звісно, вони повинні мати тимчасовий характер і зумовлюватися нормативним актом держави разової дії. Таким актом $\epsilon$, зокрема, мораторій. У разі його нормативного введення право на позов припиняє своє існування не тому, що зникли матеріальні для нього підстави, а у зв'язку з неможливістю його судового здійснення.

Мораторій, як це слідує з ч. 2) ст. 263 ЦКУ, $\epsilon$ способом відстрочення виконання зобов'язання. Як бачимо, існування мораторію призводить до неможливості захисту суб'єктивного права у зв'язку з відстроченням факту правопорушення, позаяк законодавство на певний час віддаляє момент виконання обов'язку боржника (відстрочення виконання зобов'язання або мораторій). Наразі необхідно ретельно підійти до з'ясування того, яким чином він впливає на можливість подання позову, його розгляду чи виконання судового рішення. Зрештою, чи може введення мораторію реально призвести до зупинення давності? Ha наше переконання, запровадження такої обставини, як мораторій, у цій іпостасі, тобто як правова підстава для зупинення давності, $\epsilon$ помилкою законодавця. Мораторій (як акт, що забороняє вчиняти певні дії) не повинен вносити зміни до змісту цивільно-правового зобов'язання. Скажімо, строк виконання зобов'язання для боржника настав, що $€$ безспірним фактом. Мораторій має встановлювати заборону на виконання (зокрема, примусове) такого зобов'язання і впливати не на стан самого цивільного правовідношення, 
а на можливість його реалізації. Аналіз чинних нормативних актів, якими в Україні введені мораторії, якраз і доводить, що за своєю сутністю він $€$ не відстроченням виконання обов'язку, а забороною вчиняти певні види діяльності [4, ст. 3; 5, ст. 2]. Зважаючи на викладене, доцільно пункт 2) ч. 1 ст. 263 ЦК об'єднати його 3 пунктом 3) цієї статті або викласти в такій редакції: «- у разі заборони виконання зобов'язання (мораторій), встановленої законом».

У тому ж вигляді, який мораторій має зараз (як спосіб відстрочення виконання зобов'язання), він $є$ не дієвим, а шкідливим явищем, бо його практичне застосування спотворює загальнотеоретичні принципи темпорального регулювання цивільних відносин. Відбувається невиправдане змішування чинників, котрі характеризують різні відносини (регулятивні та охоронні). Пояснімо детальніше. Якщо мораторій відстрочив виконання регулятивного зобов'язання, то до його закінчення обов'язок боржника щодо виконання в певний строк буде вважатися таким, що не настав, а суб'єктивне право кредитора не буде порушеним, тому і не забезпечене позовом. До порушення матеріального права перебіг позовної давності не відбувається, тому не може йтися про зупинення перебігу, що ще не почався. Отже, відсутність давнісного перебігу протягом тривалості відстрочення зобов'язання пояснюється не зупиненням давності, а тим, що цей строк взагалі не починається, оскільки саме виконання регулятивного обов'язку і можливість невиконання (порушення) перенесені на майбутнє. Ні законодавче відстрочення виконання зобов'язання, ні встановлення нових строків виконання обов'язків не впливає на перебіг позовної давності, яка тільки має початися після майбутнього порушення суб'єктивного права. Відстрочення зобов'язання (регулятивного) ніколи не тягне зупинення позовної давності, котра в такому разі просто не починається. 3 іншого боку, не можна відстрочити прострочене виконання, бо його регулятивний стан припинився вже в момент правопорушення, а охоронне відношення, що виникло в цей момент, за українським законодавством строком не обмежене.
Може, законодавець мав на увазі, що запровадження мораторію та відстрочення виконання перетворить охоронне відношення в регулятивне? По-перше, такий підхід суперечить усім дійсним цивілістичним традиціям; по-друге, він призведе до чергової колізії. Посудіть самі. Сторони, скажімо, домовилися про виконання обов'язку 10 червня. Після прострочення цього обов'язку починається перебіг позовної давності кредитора за відповідними вимогами. У результаті запровадження мораторію виконання відстрочується до невизначеного терміну. Чи є тепер зобов'язання порушеним? Припустімо, що ні. Обов'язок виконати 10 червня припинився нормативно (це те ж, що і договірне відстрочення обов'язку) і виник новий обов'язок із невизначеним часом виконання. За вимогами із зобов'язання, що припинилося, припинився і давнісний перебіг. Інший почнеться після невиконання обов'язку, коли настане строк такого виконання. Але $\epsilon$ ще одне. Це стосується вимог про відшкодування збитків чи стягнення штрафних санкцій за період від 10 червня до моменту прийняття мораторію. Державний акт жодним чином не повинен за логікою впливати на час існування (але це і не $\epsilon$ його функцією як документа, що лише відтерміновує виконання): відповідні домагання виникли від моменту правопорушення і тривають протягом часу, встановленого ст. 257, 258 ЦКУ.

Після закінчення встановленого строку виконання зобов'язання в межах охоронноправового відношення виникає матеріальне право на позов. За відповідними вимогами, що становлять його зміст, починається перебіг позовної давності. Якщо після цього виникне законодавчий акт про заборону виконання зобов'язання чи зупинення дії законодавства, яке регулює ці відносини, це не можна вважати зупиненням (перенесенням строку виконання) зобов'язання, адже строк виконання регулятивного зобов'язання вже закінчився, тому воно припинилося. А відстрочити (перенести) можна лише той строк, що ще не почався або триває. Попри своє номінальне призначення, такий акт припиняє охоронно-правовий обов'язок боржника виконати зобов'язання (що входить до складу охоронного правовідношення), а з ним припиняється перебіг давнісного 
строку за відповідними вимогами. Після припинення дії правового акта і настання нового строку виконання виникає цивільне зобов'язання, яке в разі прострочення знову набуває позовного забезпечення. Починається черговий перебіг позовної давності за вже новим зобов'язанням. Але, повторимо, подібні неодноразові трансформації охоронного зобов'язання в регулятивне (і навпаки) суперечать відомим цивілістичним засадам.

Так, ще раз зазначимо, що мораторій у вигляді акта держави, що відтерміновує виконання обов'язку, не має права на існування серед підстав для зупинення позовної давності. Коли ж його сутність буде відповідним чином змінена і він кваліфікуватиметься як тимчасова заборона вчинення певних дій, тоді він буде виконувати своє призначення, але підлягає об'єднанню $з$ чинниками, прописаними в ч. 3) ст. 263 ЦКУ.

Якщо питання стосовно зупинення позовної давності не $\epsilon$ проблемними, то нормативне забезпечення ії̈ переривання має досить дискусійний характер. Законом визначено виключний перелік обставин, що тягнуть переривання позовної давності. Вони зазначені в статті 264 ЦК України. Це дії особи, що свідчать про визнання нею свого обов'язку та належне пред'явлення позову. У науці триває полеміка стосовно значення, юридичного змісту та наслідків впливу цих обставин на коригування порядку обчислення давнісного строку через його переривання. Це стосується як чинників, пов'язаних із визнанням боргу (меншою мірою і суто щодо зовнішніх виявів ознак такого визнання), так і чинників, пов'язаних із поданням позову (основна полеміка саме тут).

Отже, вчинення особою дії, що свідчить про визнання нею свого боргу або іншого обов'язку, законом кваліфіковано як підставу для переривання перебігу позовної давності (ч. 1 ст. 264 ЦК). Ця норма суттєво відрізняється від положень законодавства, що діяло раніше. Згідно з Цивільним кодексом 1963 року можливість переривання позовної давності через визнання боргу припускалася лише щодо відносин, у яких однією чи обома сторонами є фізичні особи (ст. 79 ЦК УРСР). Тепер указана норма набувала більш широкого застосування.
Чинний Цивільний кодекс України розповсюдив вищевказане правило щодо переривання перебігу позовної давності на спори за участю всіх суб'єктів цивільного права. Це не тільки відповідає основним принципам цивілістики, а й вносить визначеність у відносини між суб'єктами господарювання. Визнання боргу навіть без подальшого повного виконання обов'язку саме тому визнано законодавством обставиною, яка тягне переривання позовної давності, що в результаті такого визнання на певний час втрачається невизначеність у відносинах між кредитором та боржником. Саме так досягається та мета, заради якої і був запроваджений коментований правовий інститут.

Цивільний закон не визначає ні характеру, ні способу тих дій боржника, котрі можуть кваліфікуватися як визнання боргу. Тож маємо керуватися напрацюваннями науковців та правозастосовної практики. У літературі була висловлена думка про односторонність дій боржника в разі визнання ним свого обов'язку. Дійсно, окремі дії, що свідчать про визнання боргу, як-от часткове виконання, сплата відсотків тощо, безумовно, $\epsilon$ односторонніми правочинами. Однак не завжди під час визнання боргу воля особи може спрямовуватися на встановлення, зміну або припинення прав чи обов'язків, часто вона направлена на підтвердження факту існування обов'язку, який із часом міг бути позбавлений примусового впливу з боку правовласника, хоча і не був сумнівним. Більш вдалим $\epsilon$ визначення М.А. Гурвича, згідно з яким визнання боргу, не створюючи нових, забезпечує збереження старих обов'язків на майбутній період, оскільки такий обов'язок та кореспондувальне йому право мають припинитися після завершення строку давності [6, с. 24]. Його можна прийняти, але з обов'язковим застереженням про те, що йдеться про дієвість охоронної позовної вимоги.

Єдиних критеріїв стосовно того, які саме вчинки боржника слід кваліфікувати як визнання ним боргу, в літературі та на практиці не встановлено [7, с. 130]. Як правило, такими визнаються часткове виконання основного зобов'язання, сплата відсотків чи звернення із заявою до кредитора про відстрочення обов'язку. 
Зважаючи на тематику цього дослідження, саме останній із вказаних способів заслуговує на додаткову увагу. За чинним законодавством учасники цивільного договору можуть змінити період виконання зобов'язання боржником як до початку перебігу позовної давності (до настання терміну його первинного виконання, тобто до порушення права), так і після нього (після сплину строку його первинного виконання, тобто після порушення права), не ризикуючи пропустити строк давності.

Природно, що сторони договору в період до сплину строку виконання зобов'язання боржником можуть за взаємною згодою змінити граничний термін такого виконання. Ця обставина буде враховуватися під час визначення початкового моменту позовної давності. Оскільки право кредитора ще не порушене, перебіг позовної давності почнеться саме з моменту такого порушення, якщо зобов'язання не буде належним чином виконане в новий строк. Причому період виконання обов'язку може бути як більшим, так і меншим за первісний. Сьогодні досить широкого поширення в українському суспільстві в процесі регулювання цивільних та господарських відносин набули так звані договори про реструктуризацію боргу (розстрочку боргу тощо). Ідеться про зумовлену сторонами в додатковій угоді зміну термінів виконання зобов'язання і розбивку боргу за окремими періодами на майбутнє. Така реструктуризація, здійснена сторонами угоди до закінчення строку виконання зобов'язання (до його прострочення і, відповідно, до початку перебігу позовної давності), означатиме, що сторони здійснили вищеописану зміну строків виконання зобов'язання, розділивши таке виконання на частини.

Така реструктуризація майже тотожна передбаченому статтею 529 ЦК механізму виконання зобов'язань частинами. До цих зобов'язань належать такі, що випливають із договорів поставки, кредиту тощо. За такої конструкції виконання зобов'язань право кредитора слід уважати порушеним у відповідній частині в момент невиконання зобов'язання в часткові строки. Тому право на позов щодо невиконаної частини зобов'язання і перебіг позовної давності стосовно відповідної вимоги починається від дня, наступного після терміну виконання цієї частини зобов'язання. Отже, строки позовної давності обчислюються за кожною конкретною частковою вимогою. Відмінність же між зобов'язанням, що має виконуватися частинами, та реструктурованим зобов'язанням полягає лише в тому, що для останнього характерний не тільки окремий перебіг давності за кожною вимогою, а й узгоджена сторонами зміна первинних термінів початку та закінчення давності за кожним зобов'язанням. Але описане коригування регулятивного зобов'язання жодним чином не стосується перебігу позовної давності і, відповідно, можливості його переривання, позаяк воно відбувається в межах нормального розвитку цивільних взаємин.

Інша річ, коли сторони за згодою змінюють термін виконання простроченого зобов'язання, тобто такого, строк виконання якого вже минув. Наприклад, сторонами укладено додаткову угоду про розстрочення сплати грошей за поставлену продукцію та виплати їх рівними частинами протягом чотирьох років. Такий правочин не $\epsilon$ новацією, бо в такому разі зобов'язання боржника сплатити гроші, яке виникло з договору поставки, не припиняється і не заміняється на інше, сутність його необхідність передати гроші - не змінилася. Воно лише зазнало за погодженням контрагентів змін стосовно термінів виконання. У такому разі додаткова угода укладається контрагентами вже після виникнення в кредитора права на позов, а отже, після початку перебігу позовної давності. Відбувається відстрочення саме охоронноправового обов'язку, тобто того, стосовно можливості примусового виконання якого вже почався відповідний давнісний перебіг. Цей правочин прийнято кваліфікувати як різновид дії боржника, що свідчить про визнання ним боргу, і від моменту ії укладення пропонується обчислювати новий давнісний перебіг. Однак проблема тут у тому, що така конструкція суперечить фактичній природі коментованих відносин.

Неузгодженості починаються з того, що за цією угодою кінцевий термін виконання зобов'язання для нашого прикладу цілком може перебувати поза межами як позовної давності, що застосовувалася первинно 
для захисту порушеного права, так і тієї, що почалася від часу укладення додаткового договору. Виникає питання про те, чи вплине розстрочення обов'язку на перебіг позовної давності, що почався в такій ситуації, оскільки за негативної відповіді на нього укладання будь-яких договорів про реструктуризацію боргу на строк, що дорівнює позовній давності чи перевищує іiі, буде позбавленим сенсу. Вирішення питання залежить від того, який характер отримує обов'язок боржника після його розстрочення. У разі розстрочення обов'язку, що мав виконуватися в межах охоронно-правового відношення, він продовжує залишатися таким же (охоронним) чи переходить до регулятивного стану?

На перший погляд, оскільки відбувається реструктуризація охоронного зобов'язання, то й нові зобов'язання продовжують бути такими, щоб право кредитора продовжувало забезпечуватись позовною можливістю. Проте виглядає не зовсім логічним існування охоронного правовідношення, термін порушення за яким ще не настав. Якщо від часу первинного порушення до моменту розстрочення боргу в кредитора були певні позовні домагання про виконання, то після цього вони припинилися. А це означає не що інше, як відновлення регулятивного стану зобов'язання після реструктуризації. У такому стані взаємини учасників перебуватимуть аж до невиконання обов'язку протягом нового строку. Після порушення почнеться нова давність за відповідними вимогами, при цьому від кожного з термінів часткового виконання відбуватиметься окремий перебіг. Отже, про яке переривання позовної давності в момент реструктуризації боргу може йтися, коли за новим відношенням вона ще взагалі не починалася?

Підсумовуючи викладене, можемо констатувати: розстрочення обов'язку після порушення строку його виконання не може кваліфікуватися як обставина, яка тягне переривання позовної давності. Початковий перебіг давності припиняється, правовідношення переходить до регулятивного стану. Однак усі негаразди такої трансформації охоронного зобов'язання в регулятивне (із точки зору як його відповідності сутності опосередковуваних взаємин, так і доцільності запровадження) вже були нами викладені в цій роботі, коли аналізувалися наслідки відстрочення виконання не на рівні домовленості між сторонами, а через нормативне введення мораторію.

За загальним правилом дії, які свідчать про визнання особою боргу, переривають позовну давність, тобто переривають певний строк, наданий кредиторові для реалізації свого охоронного позовного цивільного права. Однак, як уже згадувалося, перервати можна лише строк, що триває. Коли перебіг його скінчиться, будь-які дії учасників цивільних правовідносин, вчинення яких могло 6 переривати давнісний строк, не потягнуть такого результату. Таким чином, визнання боргу після спливу позовної давності (зокрема, способом часткової його оплати) не є підставою для початку нового перебігу давності. У кредитора не виникає підстав у судовому порядку стягнути з боржника решту заборгованості. Проте і боржник на підставі ч. 1 ст. 267 ЦК України не може вимагати повернення виконаного.

\section{ЛITEPATУPA:}

1. Болотников И.М. Приостановление, перерыв и восстановление исковой давности. Советская юстиция. 1964. № 23. С. 3-5.

2. Федоров С.И. Институт исковой давности в делах о несостоятельности. Российский юридический журнал. 2000. № 4. С. 101-108.

3. Гуйван П.Д. Позовна давність : монографія. Харків: Право, 2012. 450 с.

4. Про мораторій на проведення суцільних рубок на гірських схилах в ялицево-букових лісах Карпатського регіону : Закон України / Верховна Рада України. Відомості Верховної Ради України. 2000, №13 (31.03.2000). Ст. 99.

5. Про мораторій на відчуження майна, яке перебуває у володінні Федерації професійних спілок України : Закон України / Верховна Рада України. Відомості Верховної Ради України. 2007, № 21 (25.05.2007). СТ. 286.

6. Гурвич М.А. Пресекательные сроки в советском гражданском праве. Москва : ВЮзИ, 1961. 80 c.

7. Фокій Б. Особливості застосування окремих норм інституту позовної давності судами загальної юрисдикції. Право України. 2002. № 12. С. 129-131. 